\title{
Study of the mechanical behavior of dune sand treated by hydraulic binders: application in the road geotechnical field
}

\author{
Smaida $\mathrm{A}^{1}{ }^{*}$, Haddadi $\mathrm{S}^{2}$, Nechnech A ${ }^{2}$ \\ 1 Civil Engineering Department, University of Djelfa, 17000 Djelfa, Algeria \\ 2 Laboratory Environment, Water, Geomechanics and Structures, (LEEGO), USTHB, Algeria \\ * Corresponding Author: smaidaali@yahoo.fr
}

Received: 18-11-2020

Accepted: 25-02-2021

\begin{abstract}
The purpose of this work consists of valorizing a local sand dune which is found in abundance in the region of Djelfa (Algeria); for use in pavement foundations. For this investigation a method of formulation has been proposed, which based on the stabilization of this material using a mixture of two hydraulic binders. Various mixtures were subjected to classification tests, tests grain size distributions, tests of compaction with modified Proctor, shear strength, tests of bearing pressure (CBR unsoaked and soaked), compressive strength and tensile strength. The results obtained have shown that some mixtures are of high mechanical characteristics and could be then used in road foundations.
\end{abstract}

Keywords: Dune sand, Hydraulic binders, Valorization, Pavements.

\section{Introduction}

The roads undergo excessive deformation at the level of their various layers. This implies the use of often very expensive maintenance work. The search for economy in projects, as well as the need to properly exploit natural resources leads to trying to make the best use of all local materials available on site. In Algeria the dune sand constitutes a huge deposit almost $60 \%$ of the territory of Algeria. The current trend of nowadays research is the exploitation of local materials. This has prompted us to perform the present contribution aiming to the valorization of local materials, in particular the dune sand, in the foundations of pavements (Mehrpazhouh, 2019); (Shalabi, 2021) and (Salour, 2017). The modern pavements are made up of three parts, subgrade, base course, and surface layers. The role of pavement foundations is essential to take up the vertical forces and to distribute the resulting normal stresses on the support ground. Previous studies done on this subject have shown that the materials used must have certain specifications in terms of their bearing capacity and their fine material content.

Many studies have been carried out with the aim of improving the mechanical characteristics of the different materials used in road construction by adding binders (cement, clay, lime, pozzolan, fly ash ...) (Grzegorz, 2006; SETRA, 2008; Tran, 2009; Segui, 2011; Ghrieb et al., 2014; Azadegan et al., 2013; Cherrak et al., 2015; Rios R et al., 2016 and Tataranni et al., 2018). In the present work, we report on the improvement of the physical and mechanical characteristics of dune sand used for road construction. It is shown that by adding a mixed hydraulic binder all the investigated features are found to be improved.

\section{Identification of Used Materials}

\subsection{Dune sand}

The studied sand comes from the region of Djelfa located about $300 \mathrm{~km}$ from Algiers to the centre of Algeria. Besides, both centre and south of Algeria are known by their huge sand dunes that constitute an important fraction of the surface of the country. Using this dune sand in the road domain is of great interest from the economic, technical and environment friendliness points of view. 
According to the GTR 2000 Soil Classification (SETRA-LCPC.GTR, 2008), dune sand belongs to the D1 class. It is characterized as permeable, incoherent, and poorly graded soil. This suggests that dune sand alone will not be sufficiently compact, and subsequently its immediate bearing index is not adequate (Reddy and Gupta, 2008; Haach et al, 2011). Therefore, a treatment of this sand with hydraulic binders as correctors will be essential.

It is clear from the chemical analysis summarized in Table 1, that our sand is siliceous, formed of a large quantity of $\mathrm{SiO}_{2}$ (silica), with the presence of some traces of calcium and magnesium species. X-ray analyzes reveal the presence of quartz with a high percentage, and traces of illite and calcite.

Table 1. Chemical composition of dune sand

\begin{tabular}{|c|c|c|c|c|c|c|c|c|c|}
\hline Oxyde & $\mathrm{SiO}_{2}$ & $\mathrm{CO}_{2}$ & $\mathrm{Fe}_{2} \mathrm{O}_{3}, \mathrm{Al}_{2} \mathrm{O}_{3}$ & $\mathrm{CaSO}_{4}, \mathrm{H}_{2} \mathrm{O}$ & $\mathrm{NaCl}$ & $\mathrm{CaCO}_{3}$ & $\mathrm{MgO}$ & P.F & $\mathrm{H}_{2} \mathrm{O}$ \\
\hline$\%$ & 93.56 & 1.49 & 1 & Traces & 0.29 & 3.39 & 0.07 & 1.73 & 0.24 \\
\hline
\end{tabular}

The physical properties of dune sand are summarized in Table 2 .

Table 2. Physical properties of the dune sand.

\begin{tabular}{|c|c|c|}
\hline Coefficient of uniformity $\mathrm{Cu}$ & 1.87 & \multirow{2}{*}{ Norme NF P18-560 } \\
\hline Coefficient of curvature Cc & 1.09 & \\
\hline Apparent density $\left(\mathrm{g} / \mathrm{cm}^{3}\right)$ & 1.48 & \multirow{2}{*}{ Norme NF P18-554 } \\
\hline Absolute density $\left(\mathrm{g} / \mathrm{cm}^{3}\right)$ & 2.54 & Norme NF P18-555 \\
\hline Visual sand equivalent (\%) & 82 & \multirow{2}{*}{ Norme NF P18-598 } \\
\hline Sand equivalent with the piston (\%) & 68 & Norme NF P94-068 \\
\hline Blue value for $100 \mathrm{~g}$ & 0.07 & Norme NF P18-540 \\
\hline Fineness modulus & 0.9 & Non \\
\cline { 1 - 2 }
\end{tabular}

\subsection{Lime}

The lime used in the present study comes from the west of Algeria. It is a slaked lime which has a low concentration of oxides such as $\mathrm{SiO}_{2}$ (silicate) $<2.2 \%$ and $\mathrm{MgO}$ (aluminate) $<0.4 \%$ and a high concentration of basic elements such as $\mathrm{CaO}$ (free lime) $<67.4 \%$ and $73.25 \%$, with more than $90 \%$ passing through $80 \mu \mathrm{m}$ sieve. Its absolute density is $2.559 \mathrm{~g} / \mathrm{cm}^{3}$, and its specific surface area is $11053 \mathrm{~cm}^{2} / \mathrm{g}$. Table 3 summarizes the chemical composition of the lime.

Table 3. Chemical composition of the lime.

\begin{tabular}{|c|c|c|c|c|c|c|c|}
\hline Cao & Mgo & $\mathrm{Fe}_{2} \mathrm{O}_{3}$ & $\mathrm{AL}_{2} \mathrm{O}_{3}$ & $\mathrm{SiO}_{2}$ & $\mathrm{SO}_{3}$ & $\mathrm{CO}_{2}$ & $\mathrm{CaCO}_{3}$ \\
\hline \hline$>67.4 \%$ & $<0.4 \%$ & $<2 \%$ & $<1 \%$ & $<2.2 \%$ & $<1 \%$ & $<5 \%$ & $<10 \%$ \\
\hline
\end{tabular}

\subsection{Natural pozzolan}

The used natural pozzolan is of volcanic origin extracted from the Bouhamidi deposit (western Algeria). This pozzolan consists mainly of well-stratified slate and pumice stones, ranging in color from red to black. The natural pozzolan used in all tests is in the form of a powder resulting from the crushing of pozzolanic slags; steamed for 24 hours at a temperature of $50^{\circ} \mathrm{C}$ to remove their moisture, and then crushed until the resulting powder can pass through a sieve mesh of 80 $\mu \mathrm{m}$ (Figures 1 and 2).

X-ray diffraction of this pozzolan shows that it consists of crystalline minerals rich in silica, alumina, iron and magnesium. The chemical composition of natural pozzolan after grinding is shown in Table 4.

It is noted that the Blaine specific surface of natural pozzolan is $4330 \mathrm{~cm}^{2} / \mathrm{g}$ with an absolute density of $2.45 \mathrm{~g} / \mathrm{cm}^{3}$. 


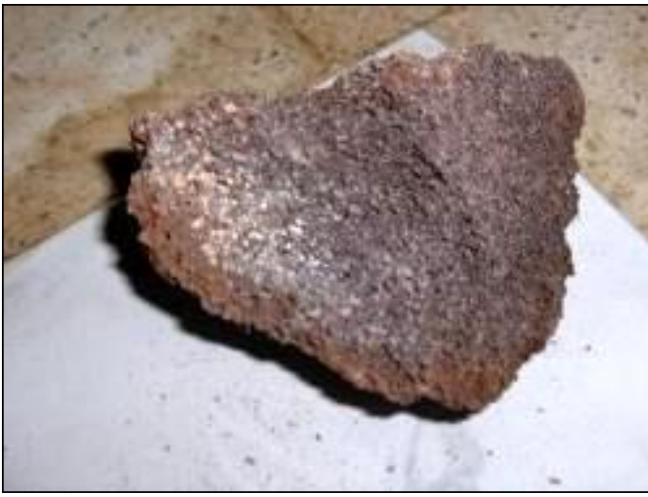

Fig 1. Slags of natural pozzolan before grinding.

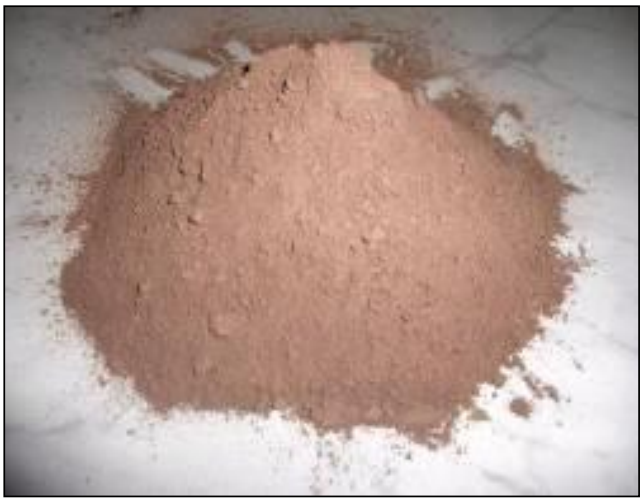

Fig 2. Powder of natural pozzolan after grinding $<80 \mu \mathrm{m}$.

Table 4. Chemical composition of natural pozzolan.

\begin{tabular}{|c|c|c|c|c|c|c|c|c|c|}
\hline $\mathrm{CaO}$ & $\mathrm{SiO}_{2}$ & $\mathrm{Al}_{2} \mathrm{O}_{3}$ & $\mathrm{Fe}_{2} \mathrm{O}_{3}$ & $\mathrm{SO}_{3}$ & $\mathrm{~K}_{2} \mathrm{O}$ & $\mathrm{Na}_{2} \mathrm{O}$ & $\mathrm{MgO}$ & $\mathrm{Cl}$ & $\mathrm{CaCO}_{3}$ \\
\hline \hline $12.36 \%$ & $42.95 \%$ & $16.32 \%$ & $9.49 \%$ & $0.01 \%$ & $1.39 \%$ & $3.00 \%$ & $4.20 \%$ & $0.00 \%$ & $10.75 \%$ \\
\hline
\end{tabular}

\section{Test methods}

The stabilization of the studied dune sand is carried out by adding mass substitutes to act on the physical and mechanical behavior:

- Physical stabilization: correction of the grading by adding $10 \%, 15 \%, 20 \%$ and $25 \%$ of fine elements (pozzolan+lime), where those percentages are chosen according to the recommendations of the standards of road networks (SETRA-LCPC, 1998).

- Mechanical stabilization: densification by compaction operation.

The mixtures are denoted by DS-Pz-Li; where DS is the dune sand, Pz the percentage of pozzolan, $\mathrm{Li}$ the percentage of lime respectively. Details of the mixtures proportions are given in Table 5 .

Table 5. Mixtures proportions.

\begin{tabular}{|c|c|c|c|c|}
\hline Mixtures & \% of Dune Sand & $\begin{array}{c}\text { \% of Natural } \\
\text { Pozzolan }\end{array}$ & \% of Lime & $\begin{array}{c}\text { \% of } \\
\text { (Pozzolan+Lime) }\end{array}$ \\
\hline \hline DS 100-0-0 & 100 & 0 & 0 & 0 \\
\hline DS 90-8-2 & 90 & 8 & 2 & 10 \\
\hline DS 85-12-3 & 85 & 12 & 3 & 15 \\
\hline DS 80-16-4 & 80 & 16 & 4 & 20 \\
\hline DS 75-20-5 & 75 & 20 & 5 & 25 \\
\hline
\end{tabular}

\section{Evolution of the Physical and Mechanical Characteristics}

\subsection{Grain size distributions}

Figure 3 shows the grain size distributions of the mixtures according to the standard NF P18560. There is a slight upward shift of the curve. This shift becomes more accentuated as the percentage of additive (pozzolan+lime)) is increased. This can indicate an increase in the fraction of fine elements in favor of a decrease of larger elements (Ismael, 2006; Tataranni, 2018) especially those less than $0.2 \mathrm{~mm}$.

Dubois (2006) has reported that the fraction of fines (\% of particles whose diameter is less than $63 \mu \mathrm{m}$ ) in the mixture is more critical for providing adequate bearing capacity. The fine fraction was limited to $20 \%$ in its mixtures. Schlosser (1988) has set two criteria as for respecting uniformity of curvature. These two criteria are expressed as,

$\mathrm{Cu}=\mathrm{d} 60 / \mathrm{d} 10>6 ; \mathrm{Cc}=\mathrm{d} 30^{2} /(\mathrm{d} 60 \times \mathrm{d} 10) ;$

$\mathrm{Cu}$ and $\mathrm{Cc}$ are in between 1 and 3 . 
Accordingly, two among our mixtures (DS 80-16-4 and DS 75-20-5) do fulfill these criteria; with a small advantage for the last mixture

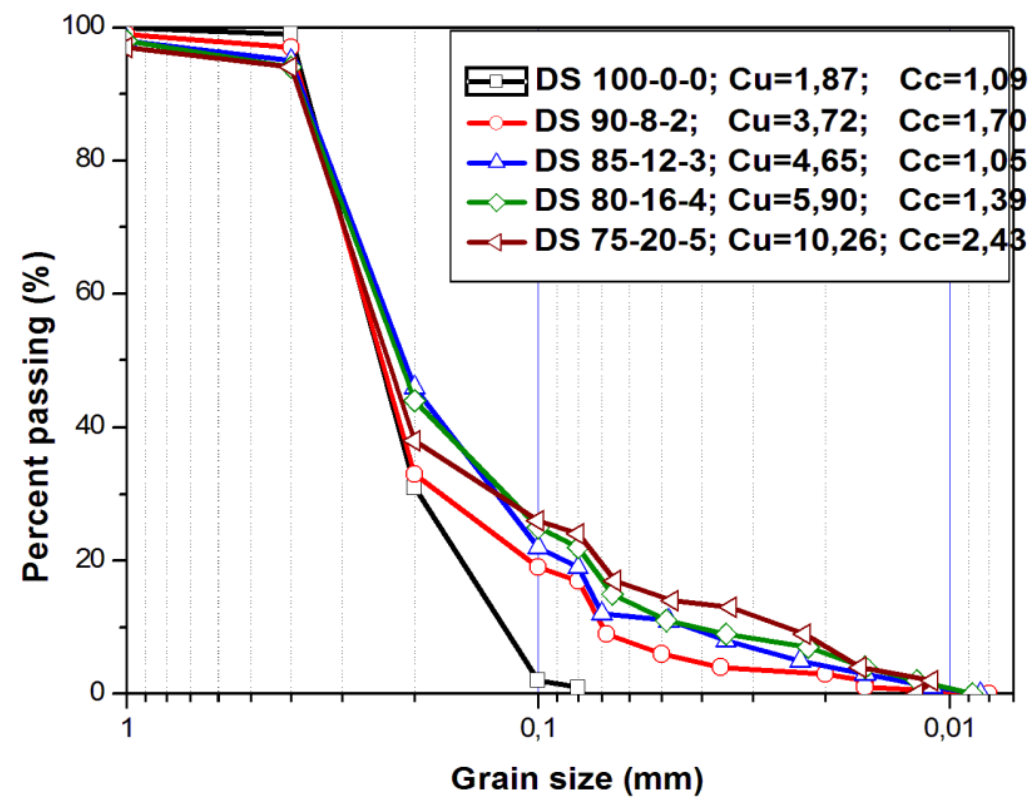

Fig 3. Grain size distribution.

\subsection{Evolution of the Proctor Characteristics}

These mixtures studied have been first compacted at different water contents in order to determine the optimal water content along with the maximal dry density via the modified Proctor test according to the NF P94-093 normalization.

By inspecting Figure 4, one can see that the dry density of the mixtures is increased with a notable shift of the Proctor curve to the right, and hence towards higher water contents. This is because of the binders absorb a part of the available water to their hydration resulting thus in the diminution of the water proportion acting as lubricant. Furthermore, hydraulic binders are fine particles that can help to obtain an improved granulometric distribution by reducing voids.

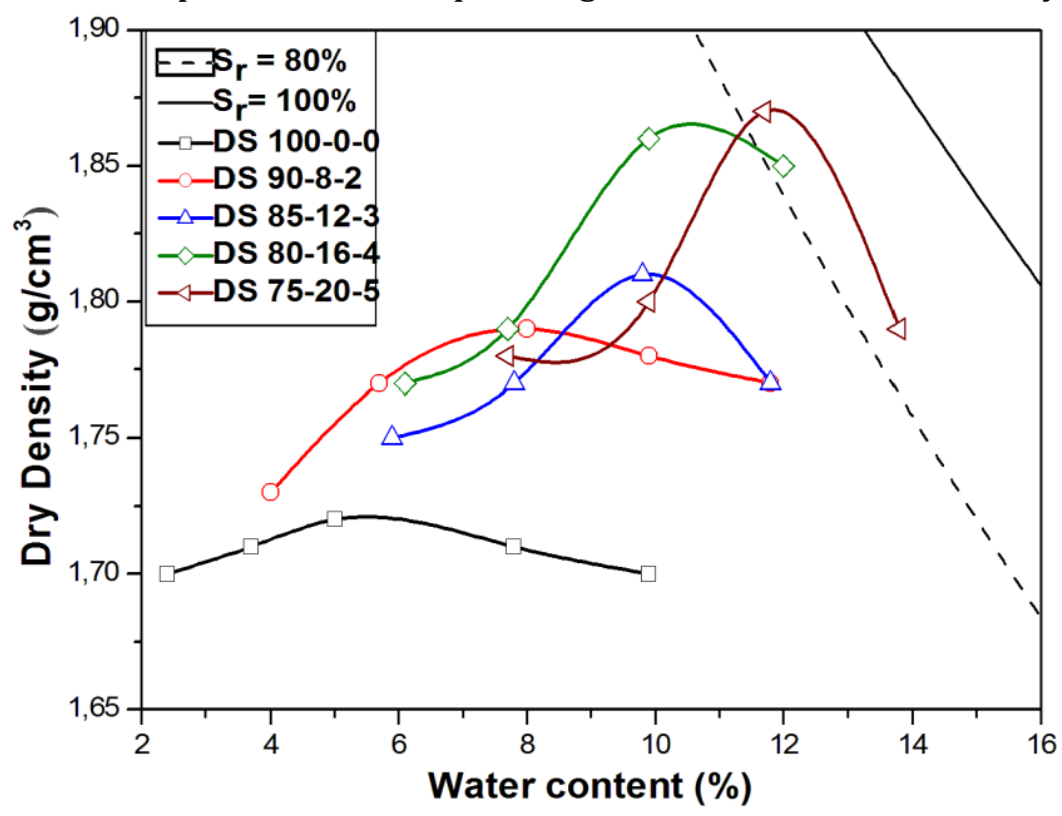

Fig 4. Modified Proctor cure according to the percentage of pozzolan+lime. 
The sand incorporation has permitted to densify the material by increasing its density from 1.72 $\mathrm{g} / \mathrm{cm}^{3}$ à $1.87 \mathrm{~g} / \mathrm{cm}^{3}$ and its optimal water content (Figure 5) from 5\% to $11 \%$. Our results show that the incorporation of pozzolan + lime tends to improve the compaction optimal characteristics of the mixtures as compared to those of the dune sand with no adding.

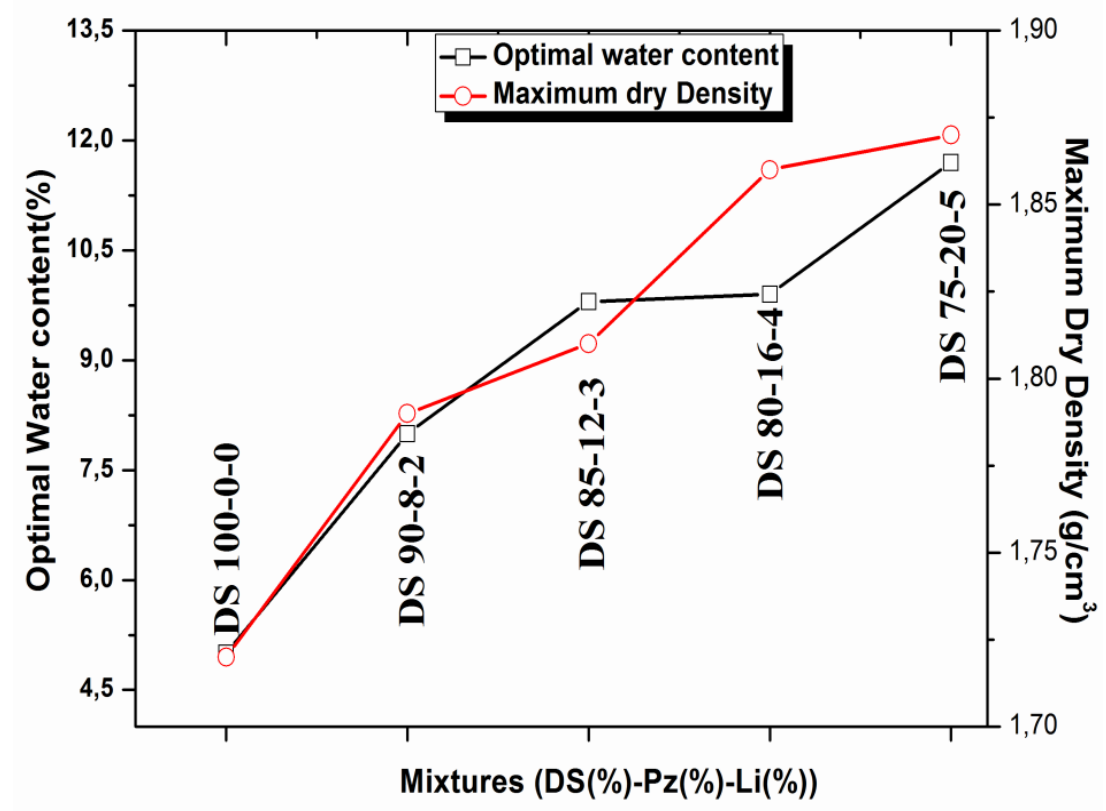

Fig 5. Optimum water content and maximum dry density according to the percentage of pozzolan + lime.

\subsection{Evolution of direct shear strength}

The studied mixtures are statically compacted at the Proctor optimum prior to placement in the straight shear box. The test mode is conditioned by a fast speed of $1 \mathrm{~mm} / \mathrm{min}$ corresponding to an unconsolidated undrained test (UU) according to the standard NF P 94-071-1. Figure 6 shows the variation of the shear strength as a function of the normal stress.

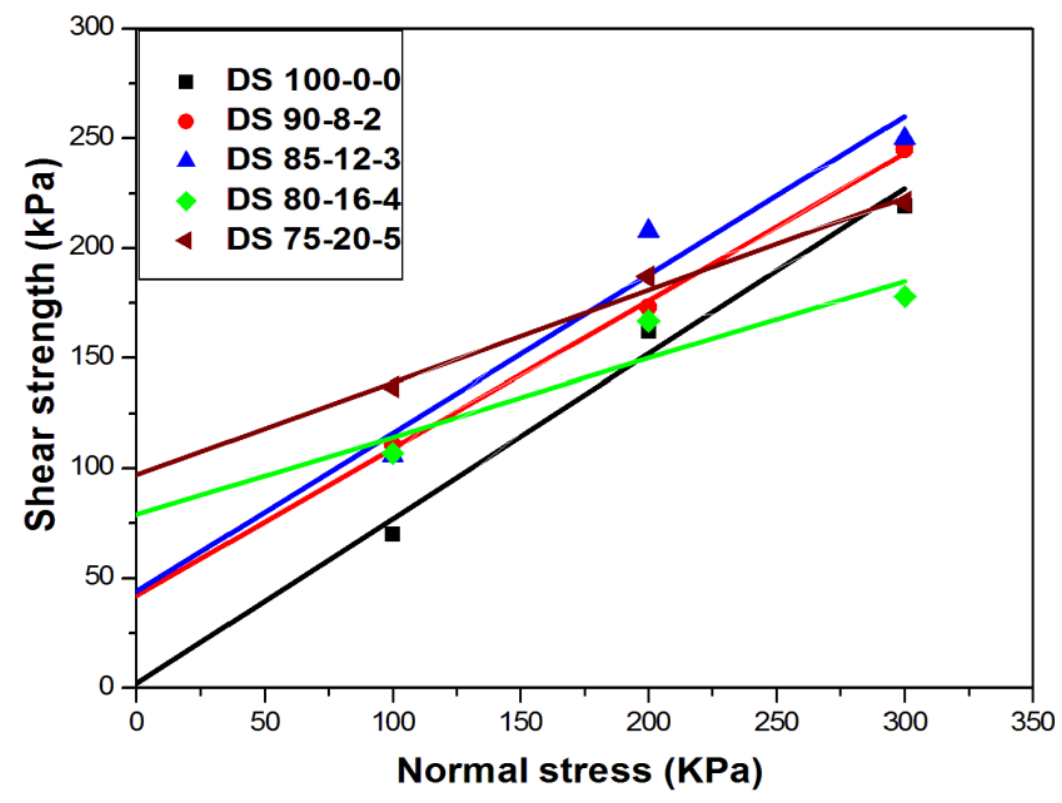

Fig 6. Intrinsic curves for the mixtures. 
The cohesion of a soil represents the internal forces of attraction defined between the particles, allowing to hold firmly between them and to ensure a physical coherence. So, for a sand, the cohesion of the grains is considered to be zero $(\mathrm{c}=0 \mathrm{kPa})$.

From Figure 6, we note that the shear strength improves with the increase of the dosage of the hydraulic binder. This evolution is usually accompanied by an increase of the cohesion and a decrease of the angle of friction (Figure 7).

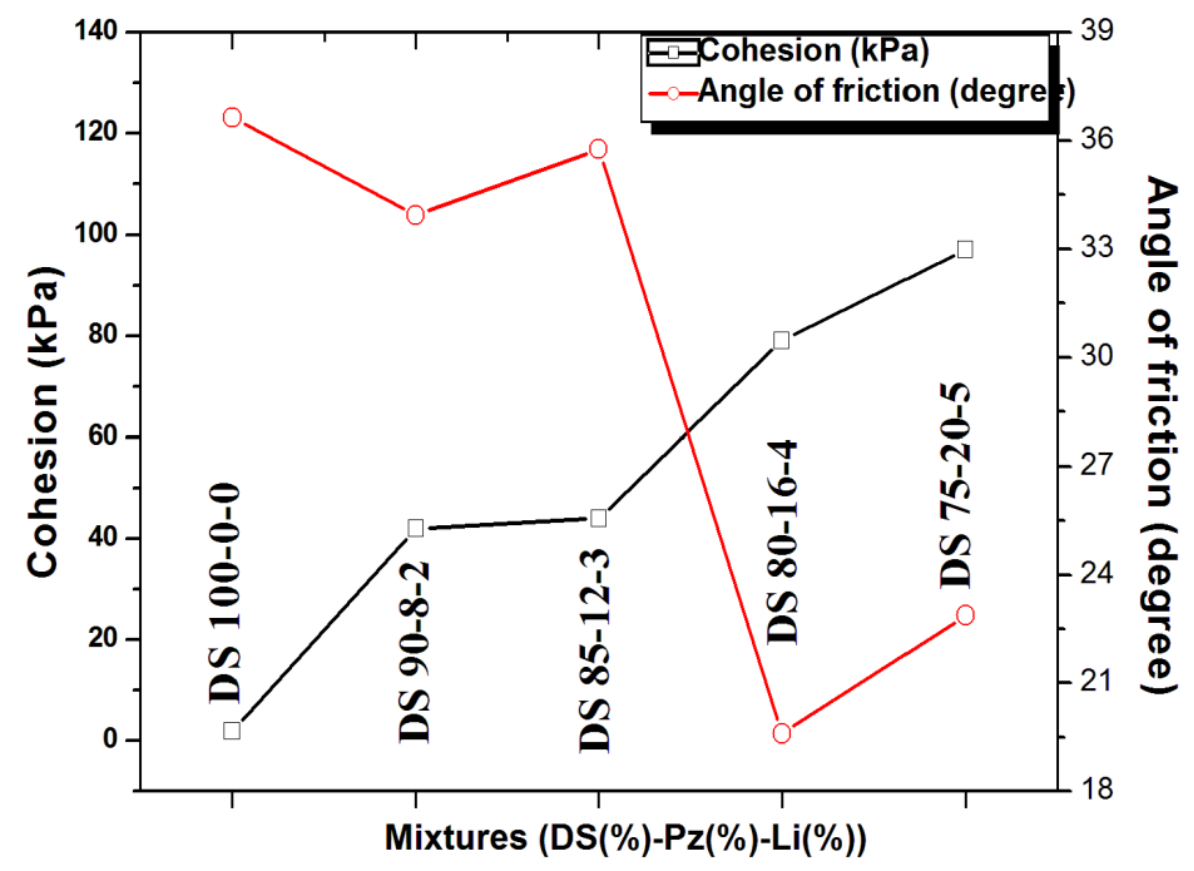

Fig 7. Evolution of cohesion and angle of friction for the mixtures

The mixtures showed that the cohesion steadily increases from 0.02 bars for dune sand untreated (incoherent material) to a maximum value of 0.79 and 0.97 bars, respectively for the mixture DS 80-16-4 and DS 75-20-5. Therefore, the friction angle decreases from $36.65^{\circ}$ to $19.6^{\circ}$ for the DS $80-16-4$ and from $36.65^{\circ}$ to $22.88^{\circ}$ for the mixture DS $75-20-5$.

\subsection{Evolution of bearing capacity CBR (\%)}

The CBR test was carried out according to the standard NF P 94-078, where CBR (unsoaked) is determined immediately, just after compaction, or after four days of immersion (CBR soaked). The test consists of punching test specimens made at different compaction energies $(10$ blows per layer, $25 \mathrm{~b} / \mathrm{l}$ and $55 \mathrm{~b} / \mathrm{l}$ ) in the CBR mold and at water contents corresponding to the optimum of the modified Proctor test. Figure 8.a illustrates the piston pressure as a function of penetration. The CBR is determined for each compaction energy, which is used to represent the variation of the dry density as a function of the CBR, and then the CBR is determined. It corresponds to $95 \%$ of the maximum of dry density obtained in the modified Proctor test (Figure 8.b exp: DS 75-20-5). 
a)

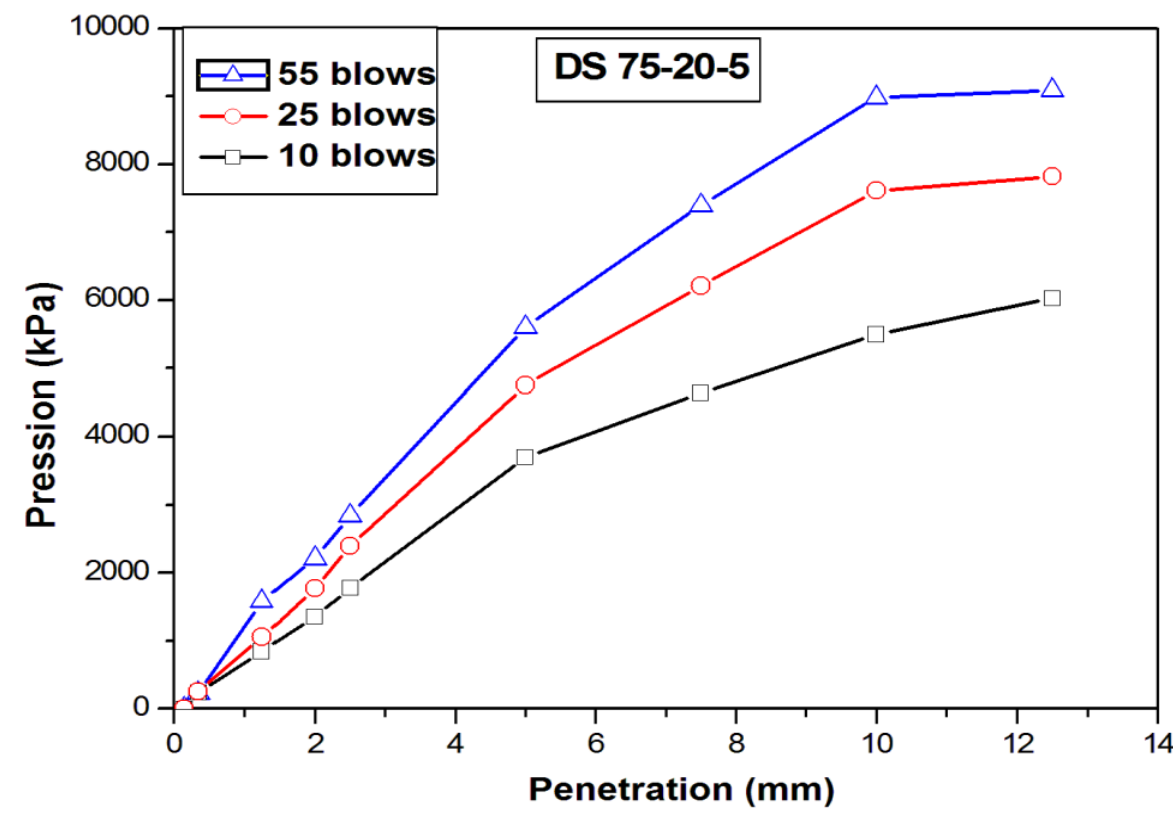

b)

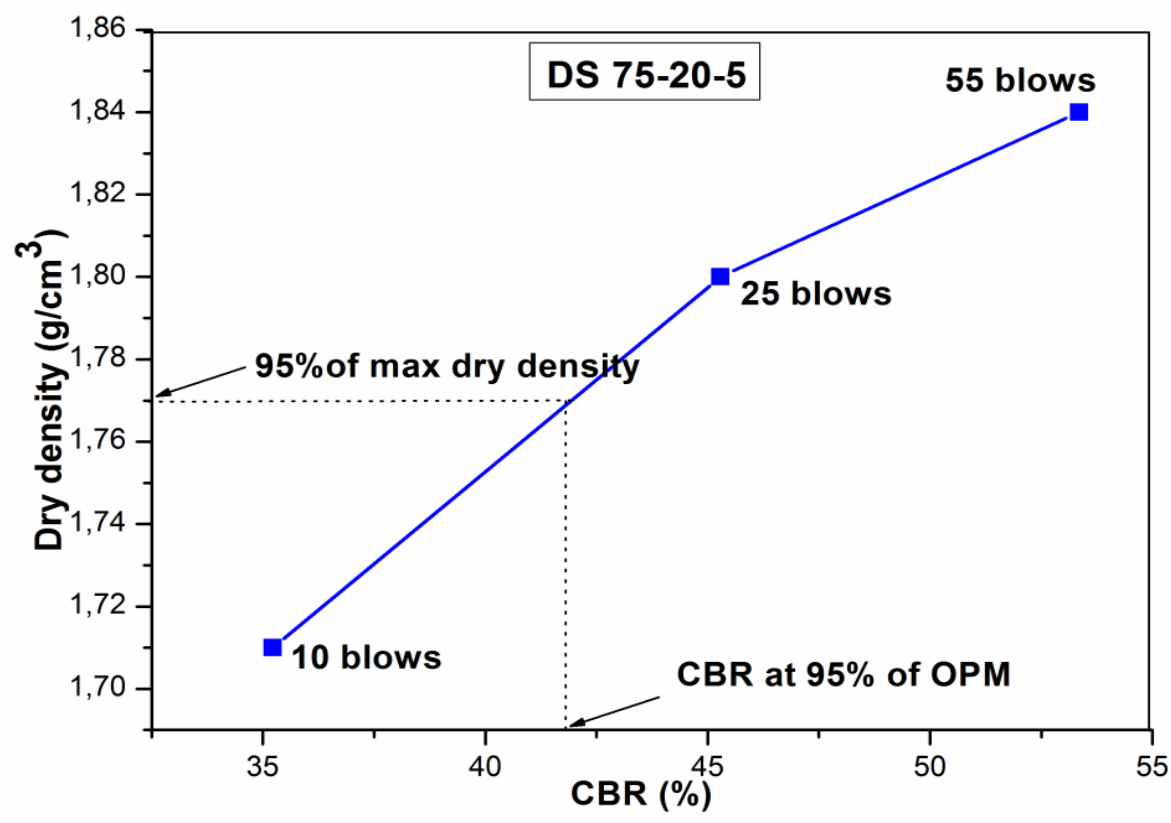

Fig 8. a) Evolution of pression according to its penetration. b) Evolution of maximum dry density according to the CBR (\%).

Figure 9 shows the added binder (pozzolan + lime) dependent evolution of the immediate load bearing has a steep slope in the range $0-25 \%$ of added binder. The unsoaked CBR increases from $8.28 \%$ up to $41.8 \%$ whereas the soaked CBR increases from $6.45 \%$ for untreated dune sand to $12.51 \%$ for DS $75-20-5$ showing a slower slope. 


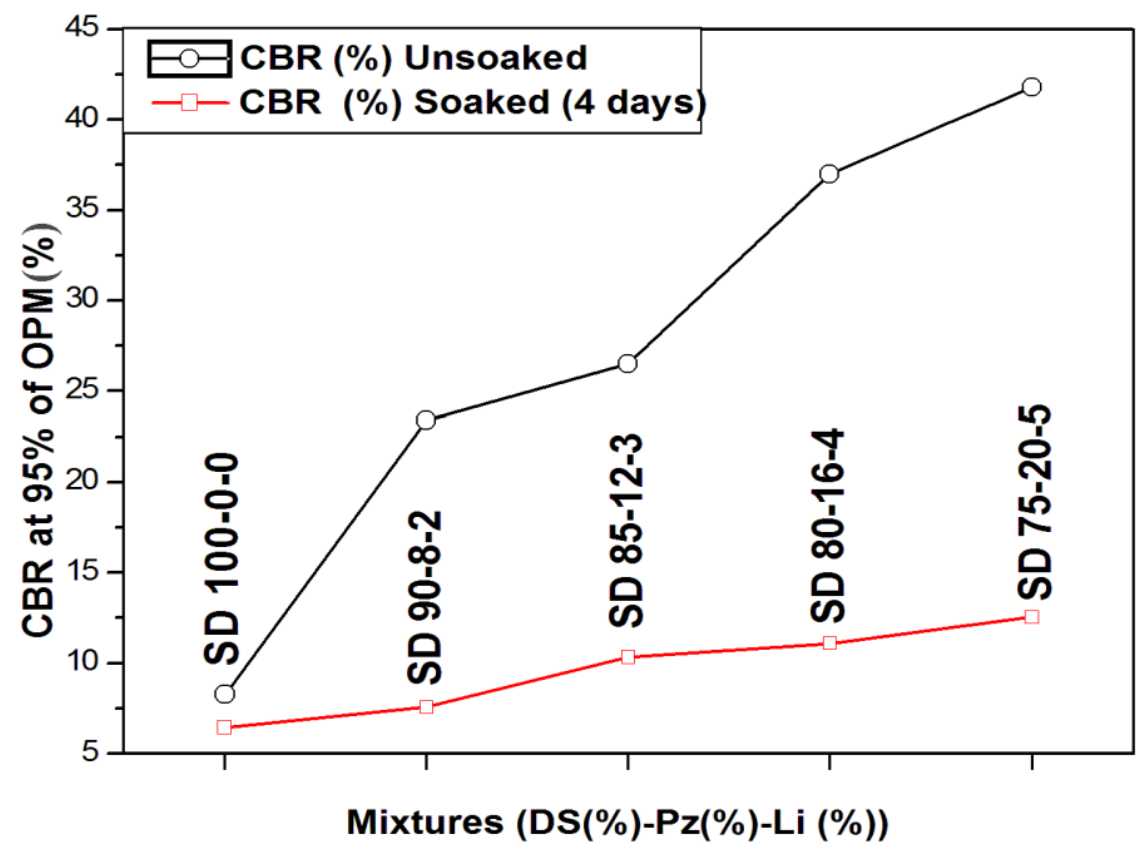

Fig 9. Evolution of CBR (\%) at 95\% of OPM according to the mixtures.

\subsection{Evolution of compression and tensile strength}

A series of cylindrical specimens with dimensions $(\varphi=100 \mathrm{~mm}, \mathrm{H}=100 \mathrm{~mm})$ was prepared according to the standard EN 13286-53, for the different mixtures. The mixture is put in a single layer in a double piston mold and then statically compacted, at the dry density and the water content of the Proctor modified according to EN 13286-41. After that the specimens were preserved in bags at a temperature of $20 \pm 2{ }^{\circ} \mathrm{C}$ until the date of the test. These tests were performed at age of 7, 14, 28, 60 and 90 days for the compressive tests; while the tests tensile were measured by the indirect tensile strength according to the standard EN 13286-42 after preparing the specimens by the same way they were preserved in bags at the same temperature until the test date of 60 days. Figure 10 illustrates the evolution of the compressive strength as a function of the percentages of the binder for different curing times and figure 10.b represent the evolution of the tensile strength as a function of the added binders.

Figure 10 shows that the compressive strength increases very significantly and follows a linear function with the increase of the quantity of (pozzolan+lime). The effect of the added binder becomes more significant beyond $15 \%$ of (pozzolan+lime). Note that compressive strength corresponding to a cure time of 90 days is greater than that corresponding to the others cure times. 


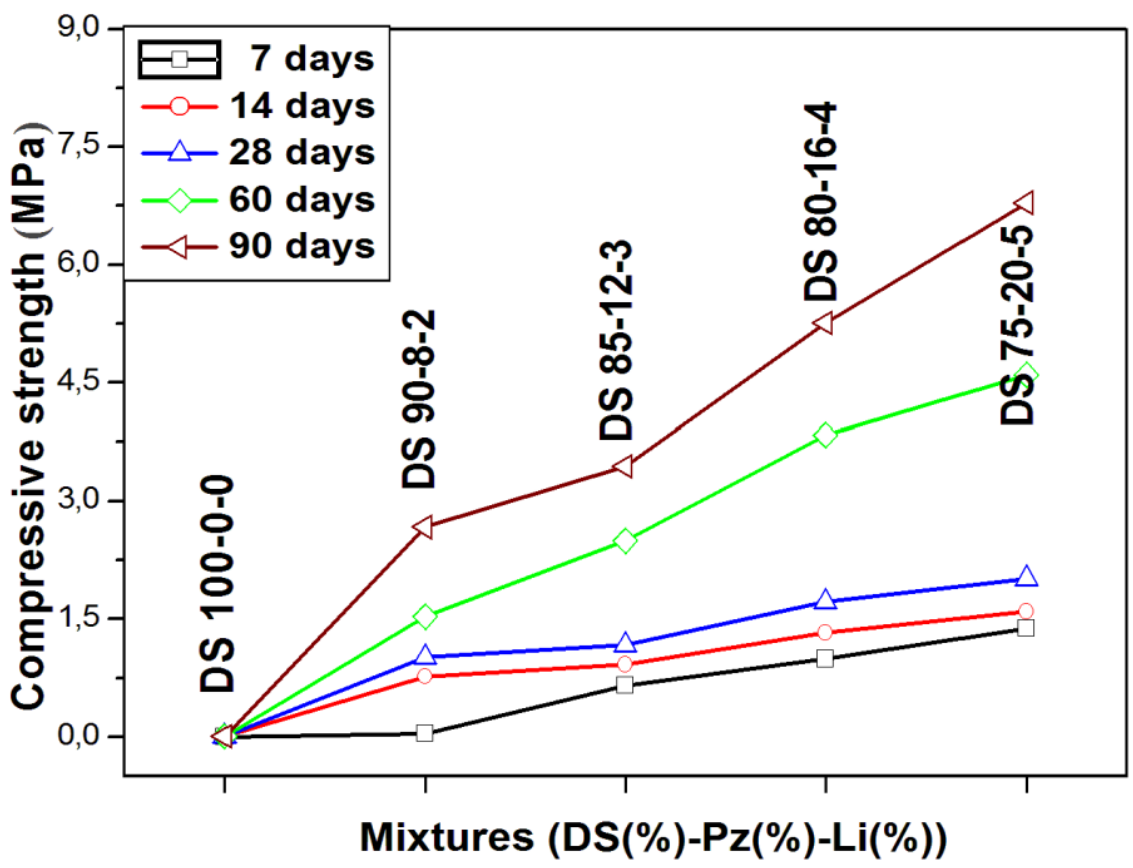

Fig 10. Evolution of the compressive strength according to the percentage of pozzolan+lime.

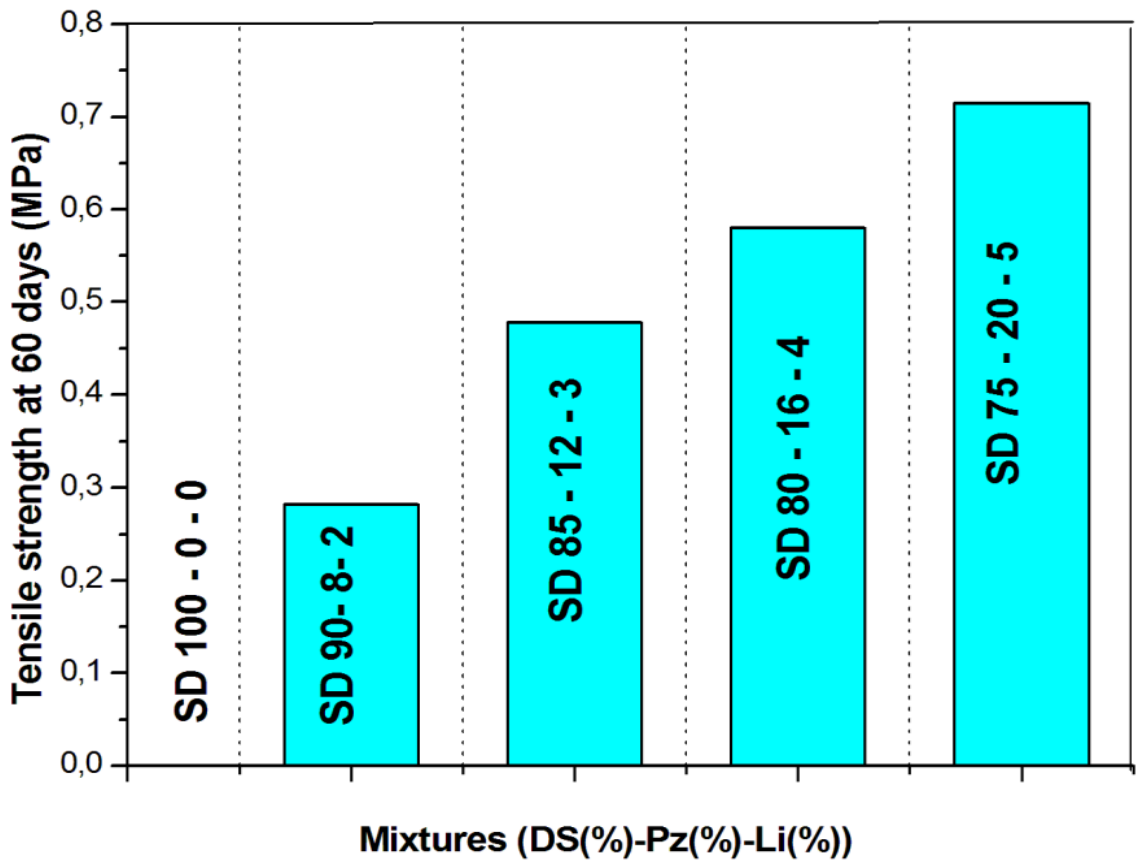

Fig 11. Evolution of the tensile strength according to the percentage of pozzolan+lime.

In a similar way to compressive strength, Figure 11 confirms an increase of the tensile strength with the proportion of added pozzolan + lime. This quantity ranges from almost zero in the case of untreated dune sand to $0.28 \mathrm{MPa}$ for $10 \%$ of binder (DS 90-8-2) giving thus a very clear idea of the effectiveness of our added binder. This is the case for all mixtures up to a maximum value of $0.71 \mathrm{MPa}$ for the mixture (DS 75-20-5). 


\section{Classification of optimal mixtures}

The standard NF 14227-1 states that there are 6 resistance classes from T0 to T5 and that T2, T3 and $\mathrm{T} 4$ are recommended for use in road layers base.

Table 6 summarized the mechanical characteristics of the mixtures.

Table 6. The mechanical characteristics of the mixtures.

\begin{tabular}{|c|c|c|c|c|}
\hline Mechanical characteristics & DS 90-8-2 & DS 85-12-3 & DS 80-16-4 & DS 75-20-5 \\
\hline Optimum water content (\%) & 8 & 9.8 & 9.9 & 11.7 \\
\hline Maximum dry density (g/cm ${ }^{3}$ ) & 1.79 & 1.81 & 1.86 & 1.87 \\
\hline CBR unsoaked at 95\% of OPM (\%) & 23.4 & 26.5 & 37 & 41.8 \\
\hline CBR soaked at 95\% of OPM (\%) & 7.57 & 10.35 & 11.1 & 12.55 \\
\hline Cohesion C (bars) & 0.42 & 0.44 & 0.79 & 0.97 \\
\hline Friction angle (degree) & 33.94 & 35.77 & 19.6 & 22.88 \\
\hline Compressive strength at 60 days (MPa) & 2.671 & 3.439 & 5.255 & 6.790 \\
\hline Tensile strength at 60 days (MPa) & 0.28 & 0.48 & 0.58 & 0.71 \\
\hline Elastic modulus (MPa) & 3123 & 4021 & 4533 & 7066 \\
\hline
\end{tabular}

The classification is based on the tensile strength-modulus of elasticity (Rt, E). The modulus of elasticity E was measured according to the standard NF 13286-43. For this classification, the curing times were considered is 60 days. The values $\mathrm{R}_{\mathrm{t} 360}, \mathrm{E}_{360}$ corresponding to a duration of one year are estimated from the ratio $\mathrm{R}_{\mathrm{t} 60} / \mathrm{R}_{\mathrm{t} 360}$ and $\mathrm{E}_{60} / \mathrm{E}_{360}$ which are respectively equal to 0.78 and 0.82 according to standard NF EN 14227-5.

The standard EN 14227-1 recommends that materials whose torque (Rt, E) is under the zone of class T2 are not used in foundation road. Fortunately, our materials are located at least in the zone T2 as shown in Figure 12 and therefore usable as a layer of seats. It is noted in particular that the mixture DS $75-20-5$ is visibly much better than the other two because it is located in the T3 zone.

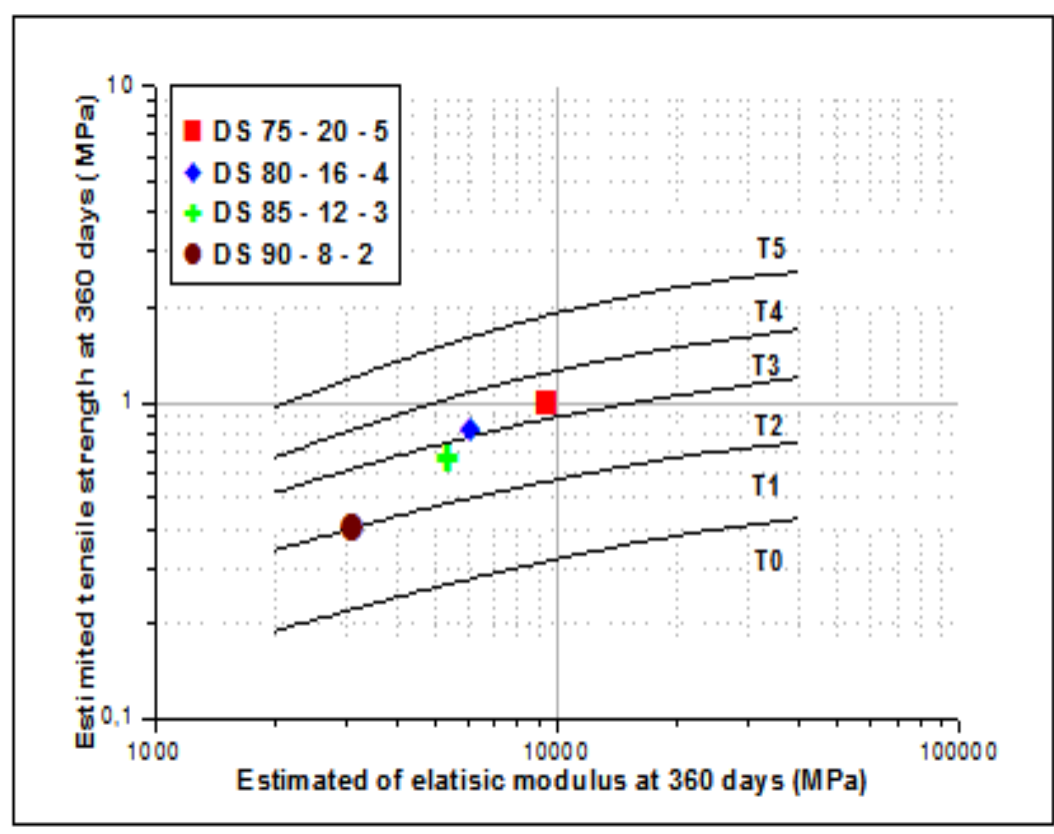

Fig 12. Classification of mixtures according to EN 14227-1. 


\section{Conclusion}

The objective of this work is to valorize dune sand in the layers of pavement foundations; this abundant material is known for its poor geotechnical properties: poorly graded, incoherent, porous, without fine elements and low bearing capacity. The improvement of these physical and mechanical properties was made by the addition of percentages of hydraulic binders (pozzolan + lime). The experimental results were very encouraging, and show that all the mixtures have resulted in sufficient mechanical characteristics to valorize this material in layers of pavement foundations, which according to these results draws the following conclusions:

- The incorporation of the pozzolan + lime percentages allowed to have mixtures with a spread and graduated curves.

- The maximum dry density and optimum water content increase proportionally to the percentages added, and therefore have a denser (compact) material.

- The Mixed hydraulic binder (pozzolan + lime) improve mechanical characteristics: bearing capacity (CBR (\%), unsoaked and soaked), shear strength, compressive strength and tensile strength.

- The modulus of elasticity increases in proportion to the percentage of binder added; which always confirms the effectiveness of binder (pozzolan + lime) used.

- The classification of our treated material shows that all the mixtures can be used in pavement foundations with an advantage for the both mixtures DS 80 - 16 - 4 and DS 75 $20-5$.

\section{References}

AFNOR 1994, NF P94-071-1. Sols ; reconnaissance et essais - essais de cisaillement rectiligne à la boîte partie 1 : Cisaillement direct.

AFNOR 1990 NF P18-555. Granulats -Mesures des masses volumiques, du coefficient d'absorption et de la teneur en eau des sables.

AFNOR 1990, NF P18-554. Granulats - Mesures des masses volumiques, de la porosité, du coefficient d'absorption et de la teneur en eau des gravillons et cailloux..

AFNOR 1990, NF P18-560. Granulats - Analyse granulométrique par tamisage.

AFNOR 1990, NF P18-598. Granulats -Equivalent de sable.

AFNOR 1994, NF P94-093. Sols : reconnaissance et essais détermination des références de compactage d'un matériau, Essai Proctor normal - Essai Proctor modifié.

AFNOR 1997, NF P18-540. Granulats - Définitions - Conformité et Spécifications.

AFNOR 1997, NF P94-078. Sols : reconnaissance et essais - Indice CBR après Immersion-Indice CBR immédiat- Indice Portant immédiat.

AFNOR 1998, NF P94-068. Sols : reconnaissance et essais - Mesure de la capacité d'adsorption de bleu de méthylène d'un sol ou d'un matériau rocheux - Détermination de la valeur de bleu de méthylène d'un sol ou d'un matériau rocheux par l'essai à la tache.

AFNOR 2003, NF EN 13286-41. Mélanges traités et mélanges non traités aux liants hydrauliques - Partie 41: méthode d'essai pour la détermination de la résistance à la

AFNOR 2003, NF EN 13286-42. Mélanges traités et mélanges non traités aux liants hydrauliques - Partie 42: méthode d'essai pour la détermination de la résistance à la traction indirect des mélanges traités aux liants hydrauliques. 
AFNOR 2003, NF EN 13286-43. Mélanges traités et mélanges non traités aux liants hydrauliques - Partie 43: méthode d'essai pour la détermination du module d'élasticité des mélanges traités aux liants hydrauliques.

AFNOR 2005, NF EN 13286-53. Mélanges traités et mélanges non traités aux liants hydrauliques - Partie 53 : méthode de confection par compression axiale des éprouvettes de matériaux traités aux liants hydrauliques.

AFNOR 2005, NF EN 14227-1. Mélanges traités aux liants hydrauliques - Partie 1: Mélanges granulaires traités au ciment.

AFNOR 2005, NF EN 14227-5. Mélanges traités aux liants hydrauliques- Spécifications Partie 5: mélanges granulaires traités au liant hydraulique routier.

Azadegan, O., Yaghoubi, E., \& Li, J. (2013). Evaluation of the performance of lime and cement treated base layers in unpaved roads. The Electronic Journal of Geotechnical Engineering, 18, 1593-1602.

Cherrak, M., Morsli, M., Boutemeur, R., \& Bali, A. (2015). Valorization of the use of calcareous tuff and dune sand in Saharan road design. Journal of Civil Engineering and Architecture, 9, 665-676.

Dubois, V. (2006). Etude du comportement physico-mécanique et caractérisation environnementale des sédiments marins-Valorisation en technique routière, Doctoral dissertation, Université d'ARTOIS.

Ghrieb, A., Mitiche-Kettab, R., \& Bali, A. (2014). Stabilization and utilization of dune sand in road engineering. Arabian Journal for Science and Engineering, 39(3), 1517-1529.

Grzegorz K. (2006). Etude de comportement mécanique des mélanges sable/Argiles. Doctoral dissertation, Institut National Des Sciences Appliquées de Lyon, France.

Haach, V. G., Vasconcelos, G., \& Lourenço, P. B. (2011). Influence of aggregates grading and water/cement ratio in workability and hardened properties of mortars. Construction and Building Materials, 25(6), 2980-2987.

Ismael, N. F. (2006). Influence of Fines on the Properties of Arid Climate Sand Deposits. In Unsaturated Soils, pp. 1617-1626.

Mehrpazhouh, A., Tafreshi, S. N. M., \& Mirzababaei, M. (2019). Impact of repeated loading on mechanical response of a reinforced sand. Journal of Rock Mechanics and Geotechnical Engineering, 11(4), 804814.

Reddy, B. V., \& Gupta, A. (2008). Influence of sand grading on the characteristics of mortars and soilcement block masonry. Construction and Building Materials, 22(8), 1614-1623.

Rios, S., da Fonseca, A. V., \& Bangaru, S. S. (2016). Silty sand stabilized with different binders. Procedia Engineering, 143, 187-195.

Salour, F., \& Erlingsson, S. (2017). Permanent deformation characteristics of silty sand subgrades from multistage RLT tests. International journal of pavement engineering, 18(3), 236-246.

Schlosser F. (1988). Eléments de mécanique des sols, Presses de l'Ecole Nationale des Ponts et Chaussées, ISBN 2-85978-104-8, 276p.

Segui, P. (2011). Elaboration de liants hydrauliques routiers à base de pouzzolane naturelle ou de cendre volante de papeterie. Doctoral dissertation, Université de Toulouse, Université Toulouse III-Paul Sabatier.

SETRA. (2008). Technical Guide. Treatement of soils with lime and / or hydraulic binders -Application to the construction of pavement base layers. 
SETRA-LCPC. (1998). Assises de chaussées - Guide d'application des normes pour le réseau routier national - En graves non traitées et matériaux traités aux liants hydrauliques.

SETRA-LCPC. GTR. (2000). Guide technique pour la réalisation des remblais et des couches de forme. Editions du SETRA-LCPC, Fascicules I \& II, 98 p. et 102 p.

Shalabi, F. I., Mazher, J., Khan, K., Amin, M. N., Albaqshi, A., Alamer, A., ... \& Alshuaibi, O. (2021). Influence of Lime and Volcanic Ash on the Properties of Dune Sand as Sustainable Construction Materials. Materials, 14(3), 645.

Tataranni, P., Sangiorgi, C., Simone, A., Vignali, V., Lantieri, C., \& Dondi, G. (2018). A laboratory and field study on 100\% Recycled Cement Bound Mixture for base layers. International Journal of Pavement Research and Technology, 11(5), 427-434.

Tran N.T. (2009). Valorisation de sédiments marins et fluviaux en technique routière. Doctoral dissertation, Université d'Artois, France. 